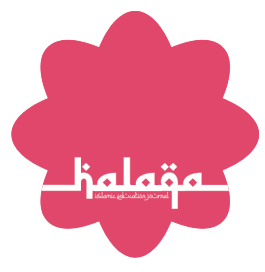

OPEN ACCESS ISSN 2503-5045 (online) ISSN 1412-9302 (print)

${ }^{*}$ Correspondence: Syirotun Nadiyah Agustin syirotunnadiyah.a@gmail.com Received: 25 November 2019 Accepted: 30 Desember 2019 Published: 21 Februari 2020

Citation:

Agustin SN and Muhammad DH (2020) Learning Method of Ta'limul Muta'allim Book in Forming Character and Improving Students' Learning Achievement.

\section{Learning Method of Ta'limul Muta'allim Book in Forming Character and Improving Students' Learning Achievement}

\section{Metode Pembelajaran Kitab Ta'limul Muta'allim dalam Pembentukan Karakter dan Meningkatkan Prestasi Belajar Santri Pondok Pesantren}

\author{
Syirotun Nadiyah Agustin*, Devy Habibi Muhammad \\ Prodi Pendidikan Agama Islam, Sekolah Tinggi Agama Islam Muhammadiyah Probolinggo, Indonesia
}

The focus of this study are: 1) How the learning methods of Ta'limul Muta'allim books in character formation, 2) How are the learning methods of Ta'limul Muta Books 'allim in improving student learning achievement, 3) What are the obstacles faced and how are the solutions. The purpose of this study are: 1) To find out how the learning methods of the Ta'limul Muta'allim book in character formation, 2) To find out the learning methods of the Ta'limul Muta'allim Book in improving student achievement, 3) To find out what are the obstacles faced and how the solution. The method used in this study uses qualitative research methods, in the process the researcher uses interview, observation, and documentation techniques. It can be concluded that learning Ta'limul Muta'allim can help students read to better understand the subject matter.

Keywords: Methods of Learning Ta'limu, Muta'allim Books, Characters, Learning Achievements, Santri Pondok Pesantren

Fokus penelitian ini adalah: 1) Bagaimana metode pembelajaran buku Ta'limul Muta'allim dalam pembentukan karakter, 2) Bagaimana metode pembelajaran Buku Ta'limul Muta'allim dalam meningkatkan prestasi belajar siswa, 3) Apa saja kendala yang dihadapi dan bagaimana solusinya. Tujuan dari penelitian ini yaitu: 1) Untuk mengetahui bagaimana metode pembelajaran kitab ta'limul muta'allim dalam pembentukan karakter, 2) Untuk mengetahui metode pembelajaran kitab ta'limul muta'allim dalam meningkatkan prestasi belajar siswa, 3) Untuk mengetahui kendala yang dihadapi dan bagaimana solusinya. Metode yang di gunakan adalah metode penelitian kualitatif, dalam prosesnya peneliti menggunakan tehnik wawancara, observasi, dan dokumentasi. Dapat disimpulkan bahwa pembelajaran ta'limul muta'allim dapat membantu siswa membaca untuk lebih memahami materi pelajaran.

Keywords: Metode Pembelajaran Kitab Ta'limul Muta'allim, Karakter, Prestasi Belajar, Santri Pondok Pesantren 


\section{PENDAHULUAN}

Dalam pendidikan secara luas masih memandang sebelah matapendidikan karakter dan sibuk dengan hal akademik. Oleh sebab itu, dalam konteks pendidikan universal, pendidikan karakter ada dan selalu berkembang atas dasar gagasan saja, tetapi sekolah memiliki tanggung jawab bagi siswa untuk menjadi cerdas, tetapi juga harus bertanggung jawab untuk memberdayakan diri mereka sendiri untuk memiliki nilai-nilai moral yang membimbing mereka dalam kehidupan seharihari.

Di negara kita kususnya indonesia, pendidikan karakter implementasinya sangat sempit, gambaran pendidikan di indonesia menjadikan motivasi dan sorotan kususnyadalam membangun pendidikan karakter. Pendidikan karakter di perlukan pengembangannya bila dilihat dari banyaknya remaja dan anak-anak yang melakukan kenakalan-kenakalan baik di dalam sekolah atau di luar sekolah. Banyaknya tingkat kenakalan remaja dan anak-anak ini dikarenakan kurang baiknya sitem pendidikan sekarang ini. Masalah yang muncul dewasa ini adalah dalam dunia pendidikan gagal dan kekurangannya misi pendidikan nasional untuk membentuk karakter bangsa.

Ahir-ahir ini banyak dari media yang memberitakan mengenai dinia pendidikan yang negatif, baik dari media cetak maupun elektronik. Salah satunya dalah berani melawan pendidik, melanggar peraturan sekolah, bolos, tawuran, berkelai, pencurian dan permasalahan yang lainnya. Tetapi saat ini didunia pendidikan, baik pendidikan formal maupun non formal membuat hidup dan lebih giat dalam memberikan pendidikan kususnya pendidikan karakter. Hal tersebut banyak kita lihat di ddunia pendidikan sudah menggunakan metode pembelajaran yang tidak hanya mengedepankan verbalitas, tetapi juga mengedepakan kepada aktualitas. Seperti contoh menanamkan nilai peduli terhadap kebersihan. Maka, seorang pendidik tidak cukup dengan membunyikan "An Nadhaafatu Minal Iiman" (kebersihan itu sebagian dari iman), tetapi pendidik juga harus juga memberikan program kepada siswa dalam kegiatan-kegiatan sekolah secara langsung atau tidak langsung sehingga dapat diaktualisasikan nilai-nilai tersebut di lingkungan sekolah maupun di luar sekolah seperti, membersihkan sampah yang ada di kelas, di halaman, tau di luar kelas sepeti di rumah dan lain-lain.

Teori behavioristik adalah teori yang sesuai untuk membentuk karakter siswa. Dalam teori behavioristik, pengalaman sehari-hari dapat mempengaruhi perilaku dan tingkah laku, ini karena adanya interaksi yang terjadiantara respon dan stimulus. Seseorang atau siswa dianggap telah belajar jikaseseorang tersebut dapat memperlihatkan perubahan dalam perilakunya. Selanjutnya teori belajar yang sering digunakan yaitu teori belajar skinner, teori belajar skinner tersebut menyebutkan bahwa yang membuat berubahnya tingkah laku adalah adanya hubungan antara respon dan stimulus yang terjadi melalui beberapa interaksi dengan lingkingan Irwan (2016) .

Kelebihan dari buku Ta’limul Mutaallim yang ditulis oleh
Syaikh Az-Zarnuji dapat memberikan penjelasan dan pengertian yang tidak terlalu rumit dan mudah difahami bahkan untuk orang awam sekalipun. Dan buku ini memberikan pedoman bagi penuntut ilmu pengetahuan atau berhati-hati dalam mencari ilmu karenabanyak seseorang dalam menari ilmu dengan jalan yang salah, tidak bisa membedakan antara fardhu kifayah dan fardhu a'in. Dalam buku ini kita semua dapat menemukan jawabannya. Buku ini sangat baik dan layak dijadikan panduan bagi siswa. Dan nilai-nilai etiket dalam buku ini bisa menjadi solusi yang tepat dalam model pendidikan karakter, bahwa pendidikan karakter harus berorientasi pada nilai adab. Dan pendidikan moral dalam buku ini memiliki nuansa pendidikan ruhiyah (kekuatan) yang mengedepankan etika rabbaniyyah (ketuhanan) Rahman (2016).

Dewasa ini persaingan di dunia pendidikan begitu tinggi. Salah satunya adalah pendidikan pesantren, pendidikan di pesantren kususnya di indonesia merupakan pendidikan tertua dan tidak boleh dilupakan begitu saja. Dan dituntut harus mampu dalam menghadapi arus globalisasi pendidikan yang semakin maju. Dan pendidikan di pesantren tidak boleh rapuh menghadapi perubahan secara global tersebut. Dalam pengamatan yang lakukan, bahwa dalam pendidikan saat ini secara global kususnya di indonesia, masih banyak mengedepankan kepentingan akademik. Padahal masih ada pendidikan yang tidak boleh dikesampingkan yaitu pendidikan karakter. Kususnya dalam dunia pesantren, karena persoalan yang ada pada akhir-akhir ini kususnya di dalam pendidikan yaitu kurang suksesnya misi pendidikan nasional dalam membentuk karakter anak bangsa.

Pembelajaran kitab ta'limul mutaallim ini sangat membantu dalam proses pendidikan karakter santri. Seperti yang di ajarkan di pondok pesantren Al-Munawwariyyah dalam membentuk karakter santri. H.M Agus Fahim selaku penpendidiks dan kepala madrasah beliau mengungkapkan bahwa keadaan santri di pondok pesantren Al-Munawwariyyah berbeda-beda dari segi sifat dan karakter.

Pondok Pesantren Al-Munawwariyah didirikan oleh KH. Muhammad Maftuh Sa'id pada tanggal 7 Syawal 1402 H./ 28 Juli 1983 M, berlokasi di Desa Sudimoro RT / RW: 12 / 04 Kecamatan Bululawang Kabupaten Malang Jawa Timur. Pendidikan di pondok pesantren al - munawwariyyah, sejak awal sudah diarahkan kepada upaya mencetak mundzirul qaum (pemimpin ummat) yang memiliki kualitas imaniyah dan ilmiyah yang seimbang. Kualitas tersebut berwujud lahirnya pribadi-pribadi ulama cendikiawan yang memiliki iman yang kuat dan sempurna serta ilmu yang luas yang pada akhirnya berimplikasi pada kemampuan melakukan amal sejati di tengah-tengah umat.

Pimpinan dan pengasuh Pondok Pesantren Al munawwariyyah, dalam sambutannya pada pembukaan ujian Tahriri akhir tahun menyampaikan, akhlak yang baik adalah kunci dari suksesnya pendidikan, pendidikan di Pondok Pesantren harus berlandaskan akhlak, karena saat santri memiliki akhlak yang bagus otomatis dia akan patuh dalam menjalani sunnah dan disiplin pondok. Keunggulan di pondok 
pesantren Al-Munawwariyyah ini yaitu tahfidz al-qur'an. Beliau KH. M. Maftuh Said selaku pembina di pondok pesantren Al-Munawwariyyah menginginkan semua santri yang menuntut ilmu di sana bisa menjadi hafidz qur'an, dan keinginan tersebut terwujud berkat hasil kerja keras beliau. Sehingga beliau bisa mencetak kurang lebih 1.200 santri hafidz qur'an.

Salah satu pembelajaran di pondok pesantren AlMunawwariyyah adalah adanya Pembelajaran Kitab Ta'limul Muta'allim. Dan ini dapat membantu dalam proses pembentukan karakter para santri mencapai prestasi belajar. Sedangkan santri-santri, datang dengan latar belakang yang berbedabeda antara santriyang satu dengan yang lain dalam hal komunikasi, tingkah laku, kecerdasan belajar, dan sikap dalam pergaulan sehari-hari. Ada santri yang sopan santun ketika diajak bicara ada pula santri yang terkesan acuh tak acuh serta menghiraukan. Ada santri yang mendengarkan dengan tekun dan penuh hikmat saat pembelajaran berlangsung ada pula yang tenang berbicara dengan teman sebelahnya.

\section{METODE PENELITIAN}

\section{Jenis Penelitian}

Jenis penelitian ini adalah studi kasus, yang merupakan studi yang mengeksplorasi masalah dengan detail, keterbatasan intensif, memiliki pengambilan data yang mendalam dan menyerahkan berbagai sumber informasi.

\section{Sumber Data}

Sumber data dari penelitian ini adalah para guru pengajar Kitab Ta'lim Mutaallim, wali kelas, para siswa,dan guru di Pondok Pesantren Al-Munawwariyyah yang bisa memberikan sumber informasi atau data dalam penelitian ini yang ada di lampiran data penelitian.

\section{Prosedur Pengumpulan Data}

Dalam penelitian ini, peneliti mengunakan metode dan teknik yang sesuai dan alat dalam mengumpulkan data yang relevan. Penggunaan alat dan teknik yang digunakan peneliti dalam mengumpulkan data yang tepat maka dapat diperoleh data yang sesuai dan objektif.

Prosedur pengumpulan data dalam penelitian ini adalah : Metode wawancara, observasi dan dokumentasi.

\section{Analisis Data}

Peneliti mencatat semua data secara obyektif dan apa adanya sesuai dengan hasil observasi dan wawancara di lapangan. Selanjutnya yaitu mereduksi data. Reduksi data merupakan suatu bentuk analisis yang menggolongkan, mengarahkan, membuang yang tidak perlu dan mengorganisasikan data-data yang direduksi.
Menyusun seluruh data yang diperoleh sesuai dengan sistematika pembahasan yang telah direncanakan. Jadi, peneliti berusaha mencari model, tema, hubungan persamaan, halhal yang sering muncul, hipotesis dan sebagainya. Melakukan analisis terhadap data yang telah disusun dengan baik, untuk menjawab rumusan masalah sehingga menjadi suatukesimpulan.

\section{Pengecekan Keabsahan Data}

Untuk kebutuhan tersebut peneliti menggunakan teknik pemeriksaan data sebagai berikut :

1. Triangulasi. Adapun cara yang peneliti tempuh adalah dengan membandingkan data hasil wawancara, hasil observasi dan dokumentasi (silang beda metode).

2. Perpanjangan Keikutsertaan. Untuk keperluan tersebut peneliti mempelajari kembali dan menguji kemungkinan terjadinya distorsi dalam pengumpulan data baik yang timbul dari diri sendiri atau dari responden.

Untuk keperluan tersebut peneliti mempelajari kembali dan menguji kemungkinan terjadinya distorsi dalam pengumpulan data baik yang timbul dari diri sendiri atau dari responden.

\section{HASIL DAN PEMBAHASAN}

\section{Metode Pembelajaran Kitab Ta'limul Muta'allim dalamMembentuk Karakter Siswa}

\section{Metode Qira'ah dan Metode Demonstrasi}

Membaca adalah suatu proses berfikir yang terjadi melalui poses mempersepsi dan memahami informasi serta memberikan makna terhadap bacaan, membaca pada dasarnya adalah proses mengolah informasi oleh pembaca menggunakan informasi dalam membaca dan pengetahuan sebelumnya dan pengetahuan yang telah relevan dengan informasi.

Sementara demonstrasi belajar adalah metode yang menyediakan materi pendidikan, baik menggunakan media atau alat, seperti yang ditunjukkan, dengan harapan bahwa siswa akan menjadi jelas dan mudah sementara juga bisa mempraktikkan materi yang dipraktekkan dan menjadi bekal suatu hari nanti di masyarakat.

Metode ini memberikan cara bagi siswa untuk menerapkan, menguji dan mengadaptasi teori dengan kondisi aktual, melalui latihan dan kerja di mana peserta berlatih akan mendapatkan pelajaran yang baik untuk mengembangkan dan memperbaiki keterampilan yang dibutuhkan Syahrowiyah (2016) .

\section{Metode Ceramah}

Metode ceramah termasuk metode konvensional yang lazim banyak digunakan untuk menyampaikan informasi atau pesan (termasuk materi pelajaran) yang membutuhkan uraian atau penjelasan secara lisan. Ketika seseorang melakukan tindakan 
ceramah kepada audiensi, pada umumnya juga diselingi tanya jawab atau yang kemudian menjadi kegiatan diskusi diantara penerima informasi dengan ceramah tersebut Sunarti (2013) .

\section{Metode Pembelajaran Kitab Ta'limul Muta'allim dalam Meningkatkan Prestasi Belajar Para Siswa \\ Bimbingan dan Pengawasan}

Bimbingan yang diberikan oleh pendidik kususnya guru kepada siswa bertujuan agar dapat mengenali dirinya dan juga agar bisa memecahkan masalah yang dihadapinya, baik individu atau kelompok sehingga dapat menikmati hidup dengan baik Hamalik (2009).

Pengawasan yang diberikan oleh guru adalah proses untuk memonitor beberapa aktivitas yang dilakukan oleh siswa, untuk memastikan aktivitas tersebut berjalan dengan lancar dan baik sehingga dapat terselesaikan sesuai dengan yang telah direncanakan Samsirin (2015).

Dari pemaparan di atas terkait teori yang sudah ada dan data yang peneliti temukan di lapangan tentang metode pembelajaran untuk meningkatkan prestasi belajar, peneliti menemukan suatu kesimpulan singkat tentang metode ini tidak bertentangan dengan teori yang sudah ada.

\section{Motivasi}

Motivasi bisa diartikan sebagai suatu energi yang dimilikiseseorang sehingga dapat memberikan tindakan kemauan dalam melakukan kegiatan. Kemauan tersebut bersumber dari dalam diri individu itu sendiri atau dari luar. Motivasi yang kuat akan mempengaruhi perilaku anak yang akan ditampilkan, baik dalam kegitan sehari-hari, belajar, bekerja dan lainnya Suprihatin (2015).

Teori yang peneliti temukan mengenai motivasi ialah, Menumbuhkan motivasi belajar siswa merupakan salah satu teknik dalam mengembangkan kemampuan dan kemauan belajar. Salah satu cara yang baikm untuk memberi motivasi kepada siswa dalam kegiatan belajar adalah dengan cara mengaitkan pengalaman belajar siswa dengan motivasi. Pendidik atau guru adalah seseorang yang bertanggung jawab dalam hal pembelajaran yang berlangsung disekolah untuk kepentingan siswa-siswanya.

Sehingga sebagai pendidik atau calon sebisa mungkin untuk selalu berupaya agar dapat meningkatkan motivasi belajar terutama bagi anak didik yang mengalami beberapa kesulitan dalam belajarnya dengan menggunakan beberapa upaya yang dapat dilakukan oleh pendidik yaitu 1) Menjelaskan tujuan yang ingin dicapai. 2) Memberikan motivasi siswa. 3) menciptakan situasi yang menyenangkan dalam kegitan belajar. 4) Mengguanakan beberapa metode dalam pembelajaran yang menarik. 5) Memberi pujian yang baik setiap keberhasilan anak didik. 6) memberinilai. 7) Memberi komentar terhadap hasil pekerjaan anak didik. 8) menciptakan kerjasama dan persaingan Suprihatin (2015) .

\section{Kendala-kendala Yang Dihadapi}

\section{Kenakalan}

Kenakalan santri tersebut sesuai dengan teori yang ada yang dikatakan oleh Juvenile Deliquency, prilaku yang menyimpang dan nakal yang dilakukan seseorang untuk mengabdikan dirinya kepada sosial sehingga menjadikan seseorang itu tidak sesuai dengan semestinya Rakib (2018) .

Kenakalan pada anak memang menjadi suatu hambatan yang serius dalam proses mendidik, pada umumnya kenakalan anak didik di pengaruhui oleh beberapa faktor yaitu faktor minimnya pendidikan yang berbasisspiritual danmoral dan faktor lingkungan baik lingkungan sekolah dan lingkungan masyarakat yang kurang nyaman Davega (2013).

Sesuai dengan data peneliti temukan dari hasil wawancara, sebagai berikut, Faktor lingkungan, dapat mempengaruhi tingkah dan pola pikir anak didik tersebut karena anak tersebut kehidupannya ada dilingkungan tersebut, contoh anak yang setiaphari beradadilingkungan kurang baik, maka anak itu akan mendapat sugestiuntuk menjadi tidak baik pula.

Dengan demikian, kenakalan yang menjadi penghambat proses penerapan metode di atas tidak bersimpangan dengan teori yang ada, yaitu kenakalan yang disebabkan lingkungan dan pergaulan teman membuat anak didik lebih lambat dan membutuhkan perhatian khusus guna meningkatkan prestasi belajar serta membentuk karakter siswa.

\section{Lupa}

Lupa adalah ketika kita tidak mampu untuk mengingat dan mengenali sesuatu yang telah dipelajari atau dialami. Lupa juga berarti kita tidak dapat mengingat apa yang telah kita alami atau pelajari untuk waktu yang singkat atau lama Nidawati (2013).

Dan hasil observasi yang peneliti lakukan di lapangan menunjukkan bahwa saat para santri di tanya mengenai pelajaran yang minggu lalau mereka lupa dan tidak bisa menjawab.

\section{KESIMPULAN}

Dari beberapa data penelitian yang penulis paparkan pada babbab sebelumnya dapat peneliti simpulkan sebagai berikut:

1. Metode pembelajaran Kitab Ta'limul Muta'allim dalam membentuk karakter siswa.

a. Metode Qira’ah dan Metode Demonstrasi

Dengan membaca dan membahas materi dapat membantu para santri untuk lebih memahami secara mendalam, kemudian dengan praktek langsung dari materi tersebut agar ilmu yang diperoleh dapat melekat dan bermanfaat.

b. Ceramah

Metode ini umum di digunakan, namun sangat penting 
dan baik digunakan, khususnya dalam pembelajaran akhlak ini, karena anak didik lebih banyak mendengarkan dari pada membaca, nasehat akan pentingnya sikap hormat sehingga para santri mengetahui ilmunya dan bisa mengamalkannya.

2. Metode pembelajaran Kitab Ta'limul Mutáallim dalam Meningkatkan Prestasi Belajar Para Siswa.

a. Bimbingan dan Pengawasan

Pentingnya sebuah bimbingan dan pengawasan dari guru untuk mengontrol apa yang anak didik lakukan, apalagi memang berada di lingkungan pondok pesantren sehingga lebih banyak membantu anak untuk meningkatkan prestasi belajar mereka dengan istiqomah.

b. Motivasi

Lelahnya belajar serta jenuhnya akan pembelajaran sering terjadi pada diri anak didik, maka motivasi tentu sangat penting dilakukan guna meningkatkan semangat belajar mereka agar lebih baik dan giat lagi, terutama bagi anak didik yang memang mempunyai kelemahan dalam IQ dan nilai yang kurang.

\section{REFERENCES}

Davega, V. (2013). Kenakalan Remaja dan Cara Penanggulanganya.

Hamalik, O. (2009). Psikologi Belajar dan Mengajar (Bandung: Sinar Baru Algensindo).

Irwan, N. N. (2016). Penerapan teori belajar behavioristik dalam proses pembelajaran. Jurnal Ilmu Pengetahuan Sosial 1.

Nidawati (2013). Belajar dalam Perspektif Psikologi Agama I.

Rahman, A. (2016). Pendidikan Akhlak Menurut Az-Zarnuji dalam Kitab Ta’lim al-Muta'allim, 11-11. At Ta’Dib.

Rakib, M. (2018). http://misterrakib.blogspot.co.id/2014/11/teori-kenakalanremaja-juvenile.html. (Accessed on 2018-02-28).

Samsirin (2015). Konsep Manajemen Pengawasan dalam Pendidikan Islam, 341360. At-Tảdib.

Sunarti, S. (2013). Hubungan Penerapan Metode Ceramah, Diskusi, dan Penugasan Dengan Hasil Pembelajaran Mata Pelajaran IPS/Sejarah Bagi Peserta Didik. Jur-
3. Masalah-masalah yang Terjadi di Lapangan

a. Kenakalan

Kenakalan disebabkan perbedaan karakter diri anak didik, sehingga satu dengan lainnya saling mempengaruhi, seperti bergaul dengan teman yang nakal dapat mempengaruhi kenakalan.

b. Lupa

Lupa adalah ketika kita tidak mampu untuk mengingat dan mengenali sesuatu yang telah dipelajari atau dialami. Lupa juga berarti kita tidak dapat mengingat apa yang telah kita alami atau pelajari untuk waktu yang singkat atau lama.

\section{UCAPAN TERIMA KASIH}

Tak lupa kami ucapkan terimakasih kepada rekan-rekan di Sekolah Tinggi Agama Islam Muhammadiyah Probolinggo yang selalu memberikan dukungan sehingga kami dapat menyelesaikan artikel ini.

nal Ilmiah Pendidikan Sejarah IKIP Veteran Semarang.

Suprihatin, S. (2015). Residential Perspective Requirements 3, 73-82.

Syahrowiyah, T. (2016). Motivasi Dan Hasil Belajar Pendidikan Agama Islam 10,

$1-18$.

Conflict of Interest Statement: The authors declare that the research was conducted in the absence of any commercial or financial relationships that could be construed as a potential conflict of interest.

Copyright (c) 2020 Agustin and Muhammad. This is an open-access article distributed under the terms of the Creative Commons Attribution License (CC BY). The use, distribution or reproduction in other forums is permitted, provided the original author(s) and the copyright owner(s) are credited and that the original publication in this journal is cited, in accordance with accepted academic practice. No use, distribution or reproduction is permitted which does not comply with these terms. 